\title{
ESTIMATION OF SERUM AND ASCITIC FLUID LEPTIN LEVELS IN CHRONIC LIVER DISEASE
}

\section{Gamal Saad El-Deeb*, Yasser Abd EL-Sattar El-Ghobashy**, Dr. Moumena Said Elh-amooly*. Tropical Medicine*, Medical Biochemistry**, Departments Faculty of Medicine Menoufia University.}

Corresponding Author:

Amira Mohamed Ghanem

Sirs Ellyan, Menoufia , Egypt

Amiraghanem841@gmail.com

\begin{abstract}
Background: Chronic liver diseases are considered a major health problem in the world. Leptin is a member of cytokine family secreted by the adipocytes and known to reduce food intake. It was first linked to obesity, Recent attention has been focused on the liver profibrogenic role of leptin in human and animal models so, we aimed to estimate the serum and the ascitic fluid leptin levels in chronic liver disease.

Subjects \&Method: Serum and ascitic leptin levels were measured using ELIZA test in patients with liver cirrhosis (GI), hepatocellular carcinoma (GII), fatty liver (GIII) and healthy control (GIV).

Results: Serum leptin levels were significantly elevated in the three patients groups when compared to the control group with significantly higher levels in females than males in all groups. This suggests a role of leptin in the pathogenesis and progression of chronic liver diseases. The ascitic fluid leptin levels in GI and GII were more than the serum levels suggesting intra-abdominal production of leptin.

Conclusion: The elevated leptin level in group GI and GII, patients may play a role in the pathogensis and progression of the disease. The elevation of ascitic fluid leptin levels more than serum levels in patients with hepatocellular carcinoma may suggest an intra-abdominal production of leptin.
\end{abstract}

Keywords: Leptin, Cirrhosis, hepatocellular carcinoma, fatty liver.

\section{INTRODUCTION}

O hronic liver diseases are defined by continuity of clinical or biochemical evidence of hepatic dysfunction for longer than six months (Suchy FJ) ${ }^{[1]}$. Most forms of late-stage chronic liver disease often-manifest cirrhosis (Liou Cao) ${ }^{[2]}$.Compensated cirrhosis; enough healthy liver tissue remains to carry out the important functions of the liver (UMMC, 2013; BLT, 2011) ${ }^{[3]}$. As the disease progresses to the point where there is not enough functional liver tissue remaining to support metabolic demands, "decompensated cirrhosis" emerges. A cirrhotic patient is deemed "decompensated" upon the emergence of symptoms such as ascites, variceal bleeding, hepatic encephalopathy or jaundice (Garcia-Tsao) ${ }^{[4]}$. Leptin, the product of the obese gene, is mainly producedby adipose tissues and, to a lesser extent,by tissues suchas the stomach, skeletal tissue and placenta (Zhang Y) ${ }^{[5]}$. The leptin receptor (OBR), belongs to the class I cytokine receptor family (which includes receptors for IL-6, IL-12and prolactin), and exists in at least six alternatively spliced forms with cytoplasmic domains of different length, known as OBRa, OBRb, OBRc, OBRd, OBRe and OBRf. (Tartaglia. LA.) ${ }^{[6]}$. Leptin is known to regulate energy homeostasis. Mounting evidence has advocated leptin to have a regulatory function in immunity similar to the function of a proinflammatory cytokine. Several studies have found that circulating leptin levels increase during infection and inflammation, suggesting that leptin is part of the immune response and host defense mechanisms. Leptin levels are acutely increased by many acute phase factors, such as tumor necrosis factor (TNF), interleukin (IL)-1and IL-6, and during bacterial infection, or lipopolysaccharide (LPS) challenge. Leptin acts on monocytes/macrophages by inducing eicosanoid synthesis, nitric oxide (Faggioni R) ${ }^{[7]}$, and several pro-inflammatory 
cytokines. Moreover, leptin induces chemo taxis of neutrophils and the release of oxygen radicals. The role of leptin in the innate and adaptive immune responses has also been reviewed (La Cava A) ${ }^{[8]}$. Leptin is secreted into the blood stream in a circadian rhythm and proportional to body fat mass. Although leptin serves as a regulatory mediator between the brain and the periphery through modulating the hypothalamo-pituitaryadrenal(HPA) axis, its circulating level is also regulated by hormones secreted by the HPA system, including corticosteroids, prolactin, and insulin.

Furthermore, leptin expression can be negatively regulated by fasting, beta adrenergic agonists and thiazolidinediones. In addition, leptin secretion is higher in females than in males for any given age and body fat mass, i.e. it is sexually dimorphic (Balci $\mathbf{H}$ ) [9].

Clinical data, which investigated serum leptin concentrations in patients with chronic viral hepatitis, indicated that cirrhotic patients due to HBV infection had significantly higher leptin levels compared to the controls, and serum leptin levels were associated with the stage of liver fibrosis. In addition, it was suggested that increased serum leptin levels might represent a negative prognostic factor for response to lamivudine mono-therapy in patients with chronic hepatitis B. (Lee, A. T.) ${ }^{[10]}$. Higher leptin levels were shown to be associated with cirrhosis development due to chronic HCV infection, but not with their histological features. These controversial results regarding the association of leptin with chronic HCV hepatitis needs further investigation (Manolakopoulos S)[ ${ }^{11]}$. Fatigue is a frequent and disabling symptom reported by patients with CHCV. Its mechanism is poorly understood. Recent attention has focused on the role of leptin and energy expenditure in $\mathrm{CHCV}$

(Ferrua B) ${ }^{[12]}$. There is evidence suggesting that leptin facilitates T-lymphocyte- mediated hepatotoxicity by facilitating the activation of tumour necrosis factor alpha (TNF-⿳亠丷) and interleukin 18 (IL-18), actions that may contribute to steatosis associated inflammation (Faggioni R) ${ }^{[13]}$.

December. 2018 Vol. 24; Supplement Issue 1.
There is experimental evidence indicating that leptin acts as a tumor promoter in NASH-related hepatocellular carcinoma (HCC). Liver hyperplasia was evident at an earlier stage of NAFLD and HCC was observed in higher rates in ob/ob mice; metabolic aberrations, rather than cirrhosis, initiated the hepatic neoplastic process (Yang S) ${ }^{[14]}$.

\section{SUBJECT AND METHODS}

This study was carried out on 100 individual selected from in patient clinic of Menouf Fever hospital, Tropical med. Dep. Faculty of medicine. They were 56 female and 44 male there age ranged between $(28-66)$ years with mean age $46.9 \pm 6.33$.the study is carried out from Sep. 2016 to April 2017

\section{They were divided into four groups:}

Group I: include (30 patients) with liver cirrhosis, they were $18(60 \%)$ male and 12 (40\%) female with mean age 45.5 years and they were divided into two subgroup: Group Ia: Include (15Patients) with ascites, Group Ib: Include (15 patients) without ascites, Group II: Include (30patients) with hepatocellular carcinoma. They were 20 (66.66) male and $10(33.34 \%)$ female with mean age 44.46 years they were divided into two subgroups: Group IIa: Include(15Patients) with ascites, Group IIb: Include (15 patients) without ascites, Group III: Include (20 patients) with fatty liver they were $5(25 \%)$ male and $15(75 \%)$ female with mean age 45.35 years, Group IV: Include (20 persons) healthy individuals, they were 13 (65\%) male and 7 (35\%) female there age ranged 47.2 years.

Exclusion criteria: chronic liver disease with diabetes melites, renal insuffancy obesity, pregnancy, coronery or endocrinal diseases.

N.B: The study did not exclude diabetic melites and obesity from group III.

\section{All patients and control subjected to the} following:

1- Full history taking thorough clinical examination and laboratory investigation in the form of:

Complete blood picture, Blood urea and serum creatinine, Fasting and post- prandial blood sugar. Serum cholesterol and triglycerides Liver 
Gamal et al..

function tests (total serum bilirubin, ALT, AST, LDH, Alkaline phosphatase, serum albumin and prothrombin time and activity), Alpha feto protein, Ascitic fluid examination ( chemical and bacteriological ) Estimation of serum and ascetic fluid leptin levels, Abdominal Ultrasonography.

2- Ascitic fluid samples for chemical cytological and bacteriological investigation:

- Ascitic fluid samples were collected in the same sitting of serum sample under complete aseptic conditions.

3- Estimation of serum and ascetic leptin levels:
Zagazig University Medical Journals

- This was done using direct ESA kit for quantitative determination of leptin level by Enzyme assay manufactured by diagnostic Biochem Canada.

Statistical analysis: Data was analyzed using Microsoft Excel 2007. Parametric data was expressed as means and non-parametric data was expressed as number and percentage. Student's test was done to compare between groups. Pearson Correlation Coefficient was done to correlate between different parameters among groups. Analysis of variance (ANOVA) test was used to estimate the difference between the means of more than two groups. $\mathrm{P}$ value of $<0.05$ considered non-significant, $\mathrm{P}$ value of $\leq 0.05$ considered significant, $\mathrm{P}$ value of $<0.01$ was considered highly significant.

\section{RESULTS}

Table (1): Laboratory finding of the studied groups

\begin{tabular}{|c|c|c|c|c|c|c|}
\hline & Group I & Group II & Group & Group IV & ANOVA & \\
\hline & Mean \pm SD & Mean \pm SD & $\begin{array}{c}\text { Mean } \pm \\
\text { SD }\end{array}$ & Mean \pm SD & & \\
\hline & $\mathbf{N}=\mathbf{3 0}$ & $\mathrm{N}=\mathbf{3 0}$ & $\mathrm{N}=\mathbf{2 0}$ & $\mathrm{N}=20$ & $\mathbf{F}$ & P-value \\
\hline$(\mathbf{A L T})(\mathbf{U} / \mathbf{L})$ & $\begin{array}{c}109.533 \pm \\
40.941\end{array}$ & $\begin{array}{l}71.900 \pm \\
29.139\end{array}$ & $\begin{array}{l}48.250 \pm \\
5.447\end{array}$ & $27.500 \pm 6.833$ & 39.661 & $<0.001 *$ \\
\hline$(\mathrm{AST})(\mathrm{U} / \mathrm{L})$ & $\begin{array}{c}109.433 \pm \\
36.719\end{array}$ & $\begin{array}{c}93.600 \pm \\
19.877\end{array}$ & $\begin{array}{l}33.500 \pm \\
9.822\end{array}$ & $21.800 \pm 9.088$ & 80.702 & $<0.001 *$ \\
\hline $\begin{array}{l}\text { Total serum } \\
\text { bilirubin }(\mathrm{mg} \%)\end{array}$ & $\begin{array}{c}3.813 \pm \\
1.611 \\
\end{array}$ & $\begin{array}{c}5.767 \pm \\
2.351 \\
\end{array}$ & $\begin{array}{c}0.620 \pm \\
0.317\end{array}$ & $0.630 \pm 0.298$ & 63.381 & $<0.001^{*}$ \\
\hline$(\mathrm{ALP})(\mathrm{U} / \mathrm{L})$ & $\begin{array}{c}165.733 \pm \\
67.513\end{array}$ & $\begin{array}{c}205.400 \pm \\
92.437\end{array}$ & $\begin{array}{c}127.550 \pm \\
34.327\end{array}$ & $115.100 \pm 35.389$ & 9.326 & $<0.001 *$ \\
\hline $\begin{array}{l}\text { Serum } \\
(\mathrm{g} / \mathrm{dl})\end{array} \quad$ Albumin & $\begin{array}{c}2.423 \pm \\
0.447\end{array}$ & $\begin{array}{c}2.397 \pm \\
0.506\end{array}$ & $\begin{array}{c}3.943 \pm \\
0.348\end{array}$ & 0.165 & 141.888 & $<0.001 *$ \\
\hline $\begin{array}{l}\text { Prothrombin } \\
\text { activity (\%) }\end{array}$ & $\begin{array}{c}43.733 \pm \\
21.141\end{array}$ & $\begin{array}{c}51.267 \pm \\
15.065\end{array}$ & $\begin{array}{l}92.500 \pm \\
3.706\end{array}$ & $89.050 \pm 6.143$ & 71.598 & $<0.001 *$ \\
\hline$(\mathbf{L D H})(\mathrm{U} / \mathrm{L})$ & $\begin{array}{c}132.467 \pm \\
21.299\end{array}$ & $\begin{array}{c}270.933 \pm \\
69.976\end{array}$ & $\begin{array}{c}103.700 \pm \\
10.878\end{array}$ & $77.000 \pm 15.079$ & 117.194 & $<0.001 *$ \\
\hline $\begin{array}{l}\text { Alpha fetoprotein } \\
(\mathrm{mg} / \mathrm{ml})\end{array}$ & $\begin{array}{l}82.633 \pm \\
44.562\end{array}$ & $\begin{array}{l}616.433 \pm \\
245.606\end{array}$ & $\begin{array}{l}4.395 \pm \\
1.634\end{array}$ & $6.220 \pm 1.850$ & 126.048 & $<0.001 *$ \\
\hline lood urea & $\begin{array}{c}42.833 \pm \\
6.330 \\
\end{array}$ & $\begin{array}{c}44.733 \pm \\
4.748\end{array}$ & $\begin{array}{c}41.050 \pm \\
4.236 \\
\end{array}$ & $42.050 \pm 5.165$ & 2.209 & 0.092 \\
\hline Serum Creatinine & $\begin{array}{c}0.950 \pm \\
0.136\end{array}$ & $\begin{array}{l}0.953 \pm \\
0.125\end{array}$ & $\begin{array}{c}0.875 \pm \\
0.189\end{array}$ & $0.875 \pm 0.174$ & 2.013 & 0.117 \\
\hline $\begin{array}{c}\text { Serum Cholestrol } \\
(\mathrm{mg} / \mathrm{dl})\end{array}$ & $\begin{array}{c}121.333 \pm \\
20.129\end{array}$ & $\begin{array}{c}98.200 \pm \\
4.985\end{array}$ & $\begin{array}{c}227.100 \pm \\
23.479\end{array}$ & $117.150 \pm 9.560$ & 288.138 & $<0.001^{*}$ \\
\hline $\begin{array}{c}\text { Serum } \\
\text { Triglycerides } \\
\text { (mg/dl) }\end{array}$ & $\begin{array}{c}103.033 \pm \\
18.261\end{array}$ & $\begin{array}{l}104.967 \pm \\
21.745\end{array}$ & $\begin{array}{c}167.150 \pm \\
9.938\end{array}$ & $106.800 \pm 15.168$ & 67.575 & $<0.001 *$ \\
\hline
\end{tabular}


Table (3): Serum level of leptin in the studied groups

\begin{tabular}{|l|c|c|c|c|c|c|}
\hline & Group I & Group II & Group III & Group IV & \multicolumn{2}{|c|}{ ANOVA } \\
\hline & Mean \pm SD & Mean \pm SD & Mean \pm SD & Mean \pm SD & & \\
\hline & N= 30 & N=30 & N= 20 & N= 20 & F & P-value \\
\hline $\begin{array}{l}\text { Serum level } \\
\text { of leptin }\end{array}$ & $32.07 \pm 15.625$ & $21.192 \pm 7.305$ & $15.912 \pm 5.827$ & $\begin{array}{c}12.719 \pm \\
3.449\end{array}$ & 18.595 & $<0.001^{*}$ \\
\hline
\end{tabular}

Table (4): Serum level of leptin in the studied groups

\begin{tabular}{|l|c|c|c|c|c|c|c|c|}
\hline & Group Ia & Group Ib & Group IIa & Group IIb & $\begin{array}{c}\text { Group } \\
\text { III }\end{array}$ & Group IV & \multicolumn{2}{|c|}{ ANOVA } \\
& Mean \pm SD & Mean \pm SD & Mean \pm SD & Mean \pm SD & $\begin{array}{c}\text { Mean } \pm \\
\text { SD }\end{array}$ & Mean \pm SD & & \\
\hline & $\mathbf{N}=\mathbf{1 5}$ & $\mathbf{N}=\mathbf{1 5}$ & $\mathbf{N}=\mathbf{1 5}$ & $\mathbf{N}=\mathbf{1 5}$ & $\mathbf{N}=\mathbf{2 0}$ & $\mathbf{N}=\mathbf{2 0}$ & F & P-value \\
\hline $\begin{array}{l}\text { Serum } \\
\text { level of } \\
\text { leptin }\end{array}$ & \pm 12.957 & 36.191 & 19.344 & $23.039 \pm$ & 15.912 & 12.719 & 12.968 & $<0.001^{*}$ \\
\end{tabular}

Table (5): Serum leptin and ascitic leptin in-group Ia and IIa

\begin{tabular}{|c|c|c|c|c|c|c|c|c|c|}
\hline & \multirow{2}{*}{\multicolumn{3}{|c|}{ Group Ia }} & \multirow{2}{*}{\multicolumn{3}{|c|}{ Group IIa }} & \multicolumn{2}{|l|}{ T-Test } \\
\hline & & & & & & & & $\mathbf{t}$ & P-value \\
\hline $\begin{array}{l}\text { Serum level of } \\
\text { leptin }\end{array}$ & Mean \pm SD & 27.957 & \pm & 12.719 & 19.344 & \pm & 7.749 & 2.240 & $0.033 *$ \\
\hline Ascitic leptin & Mean \pm SD & 28.459 & \pm & 8.694 & 36.626 & \pm & 11.143 & -2.238 & $0.033 *$ \\
\hline
\end{tabular}

Table (6): Serum level of leptin in relation to sex

\begin{tabular}{|c|c|c|c|c|c|c|c|c|}
\hline \multirow[t]{3}{*}{ Groups } & \multicolumn{6}{|l|}{ Sex } & \multirow{2}{*}{\multicolumn{2}{|c|}{ T-Test }} \\
\hline & \multicolumn{3}{|l|}{ Male } & \multicolumn{3}{|l|}{ Female } & & \\
\hline & Mean & \pm & SD & Mean & \pm & SD & $\mathbf{t}$ & P-value \\
\hline Group I & 29.519 & \pm & 14.824 & 40.917 & \pm & 4.562 & -2.570 & $0.016^{*}$ \\
\hline Group II & 20.748 & \pm & 11.490 & 35.500 & \pm & 4.197 & -3.903 & $0.001^{*}$ \\
\hline Group III & 15.636 & \pm & 3.067 & 16.060 & \pm & 6.999 & -0.151 & 0.881 \\
\hline Group IV & 13.258 & \pm & 3.634 & 11.719 & \pm & 3.076 & 0.949 & 0.355 \\
\hline
\end{tabular}

Table (7): Relation between sex and serum leptin \& ascetic leptin

\begin{tabular}{|c|c|c|c|c|c|c|c|c|c|}
\hline \multirow[t]{3}{*}{ Groups } & & \multicolumn{6}{|c|}{ Sex } & \multirow{2}{*}{\multicolumn{2}{|c|}{ T-Test }} \\
\hline & & \multicolumn{3}{|c|}{ Male } & \multicolumn{3}{|c|}{ Female } & & \\
\hline & & Mean & \pm & SD & Mean & \pm & SD & $\mathbf{t}$ & P-value \\
\hline \multirow{2}{*}{$\begin{array}{c}\text { Group } \\
\text { I }\end{array}$} & Serum level of leptin & 29.519 & \pm & 14.824 & 40.917 & \pm & 4.562 & -2.570 & $0.016^{*}$ \\
\hline & Ascetic leptin & 32.549 & \pm & 12.457 & 47.250 & \pm & 6.384 & -3.757 & $0.001 *$ \\
\hline \multirow{2}{*}{$\begin{array}{c}\text { Group } \\
\text { II }\end{array}$} & Serum level of leptin & 20.748 & \pm & 11.490 & 35.500 & \pm & 4.197 & -3.903 & $0.001^{*}$ \\
\hline & Ascetic leptin & 35.220 & \pm & 9.930 & 43.600 & \pm & 7.321 & -2.359 & $0.026^{*}$ \\
\hline
\end{tabular}

\section{DISCUSSION}

Chronic liver diseases may progress to fibrosis, accumulation of fibrillar extracellular matrix (ECM). Fibrosis is a dynamic process, considered as the result of a chronic "wound healing "response (Friedman SL) ${ }^{[15]}$.

Regarding hepatic cancer, there are approximately 626.000 new cases of primary liver cancer worldwide, almost all represented by hepatocellular carcinoma (HCC) with a high mortaility ratio $(0.93), 598.000$ of these patients die from this cancer each year, making HCC the third most common cause of cancer death (Parkin DM) ${ }^{[16]}$.

Leptin has proven to be important in the progession of hepatic steatosis (Magkos F1) 
${ }^{[17]}$. As a result of synergistic action of other adipocytokines such as tumor necrosis factor (TNF- $\alpha$ ), fatty liver may progress to steatohepatitis by lipoapoptosis induction, which leads to the recruitment of inflammatory cells, contributing to its progression and subsequently causing hepatocellular damage, such as cell swelling and appearance of Mallory bodies (Magkos F) ${ }^{[18]}$.Leptin has proven to be important in the progression of hepatic steatosis (Magkos F) ${ }^{[19]}$.

Our study showed significantly higher ascitic fluid leptin level compared to serum in our patient in both group I, II .

This is in agreement with (Giannini E) ${ }^{[20]}$ who reported similar results and suggested intra-abdominal production of the leptin to explain this higher level reported that is due to hyper expression in leptin mRNA on activated hepatic settlate cells and found it is correlated with fibrosis in cirrhotic patients to be source of increased the leptin in tissue and serum of patients with the chronic liver disease.

Also, ascitic fluid leptin level are remarkably higher than the serum level and ascitic fluid leptin level in average twice as high as the serum level in the patient with hepatocellur carcinoma this is due to intraabdominal production of the leptin (Van Hannelen V) ${ }^{[21]}$.

In current study, we have found highly significant correlation between serum leptin and live function tests in all studied groups. This result is in agreement with (Green $\mathbf{R}$. M.) ${ }^{[22]}$ who explain alternation due to defect synthsis of coagulation factors. In addition this result is in agreement with (Ben-Ari Z) [23] who found that the leptin level increase when the liver function worsen likely reflecting a loss in the capacity to down regulate energy expenditure.In current study the lipid profile is highly significant in all studied groups with non-significant relation between to the leptin level.This result is in agreement with the study of (Cortez- pino) [24] who demonstrated that, obesity and dyslipidaemia were observed in $80 \%$ of the patients with non - alcoholic fatty liver disease, confirming that obesity and dyslipidaemia are risk factors of non - alcoholic fatty liver disease while decrease the leptin in relation to lipid profile due to defective hepatic synthsis indicating poor prognosis (Riggio O) ${ }^{[25]}$.

The current study showed statistically significant increase of the leptin level among patients groups in comparison to control group ( $\mathrm{p}<0.05)$ while there is a nonsignificant difference between the three patient groups ( I, II , III ). The results in cirrhotic patient group were agreement with (Trayhurn P) ${ }^{[26]}$ who reported that patient's with cirrhosis had significally higher serum leptin concentration compared with noncirrhotic patients.

This due to stimulated production of some factors able to stimulate a dipocyte leptin synthsis and/or secretion of such as cytokines sexual steroids, insulin and cortisol , Moreover its possible due to development of portosystemic shunting in cirrhosis causes many of above mentioned secretogenous of leptin to increase leading to a multifactorial stimulation of leptin secretion (Testa R) ${ }^{[27]}$

This result agreed with (LeclereqlA) ${ }^{[28]}$ who reported that chronic liver injury is dependent on leptin. This result also demonstrated that leptin is required for collagen $i$. expression and production in the contex of chronic liver injury and hepatic inflammation, possibly by modulatory transforming growth factor beta I (TGFB ${ }_{1}$ ), bio-activation. These finding establish the essential physiological dependence of leptin for hepatic finbrongensis in response to chronic liver injury.

In the current study serum leptin level in patient with HCC were significantly increased when compared to that of control group $(21.192+7.305)$

This result is in agreement with (Wang SN \& Lee KT) ${ }^{[29]}$ who reported that leptin receptor $(\mathrm{ObR})$ is stimulator to class I cytokine receptors and signal transduction components of IL. 6 family of cytokine the biological action of leptin will be effective when high amounts of IL. 6 receptor activate to signaling pathways.

1) Janus Kinas ( JAR) signal transducers and it's activators to transcription (STAT16). 
2) Phosphotidylinositol 3 kinas (P13k) both promoting cell growth migration and invasion.

This study shows that, the serum leptin levels showed a statically significant increase in group III of fatty liver (Mean $15.912+5.827$ ) in comparison to the control group.

This result is in agreement with (Uygun A) ${ }^{[30]}$ reported that mean serum leptin level were signifcally higher in patient with non-alcoholic fatty liver disease (NAFLD) when compared to control group, He stated that elevated serum leptin level might promote hepatic steatosis and steatohepatitis. This prospective control study, leptin level was significantly elevated in females than males in all studied groups.

This is in agreement with (Saber A) ${ }^{[31]}$ and (McCullough A J) ${ }^{[32]}$ who reported that women have significantly greater subcutaneous adipose tissue mass relative to omental adipose mass and estrogen increase serum leptin levels while testosterone decrease it.Thus, patient's sex needs to be considered when investigating the leptin level.

In current study, we found that BMI is highly significant in all studied groups with non-significant relation is found between leptin level and BMI in all studied groups.

This is in agreement with (Tungtrongchitr R) ${ }^{[33]}$. Who found no significant correlation between the leptin level and BMI in patient that have post hepatitis liver cirrhosis are wasted and may be over dehydrated thus, the excess in extracellular fluid that occur in all stages of liver disease causes weight parameters such as BMI to be in accurate.

\section{CONCLUSIONS}

\section{From this study, we concluded that:}

Estimation of the leptin level being a good option for clinical outcomes with chronic liver disease to be predicted in clinical practic for easy clinical application, Estimation of the serum and the ascetic fluid leptin is an excellent score for prediction of chronic liver disease which may progress to liver cell failure or hepatocellular carcinoma, Ascitic fluid leptin is significally higher than the serum leptin. It may be due to intra abdominal production of leptin, Patient with ascetic fluid leptin level twice the serum leptin level predicting hepatocellular carcinoma.

\section{REFERENCES}

[1] Suchy FJ, Moseley RH, Wang W, Takeda H, Lown K, Shick L. Ananthanarayanan M, Chronic viral hepatitis in children. Semin.Pediatr.Gastroenteral.Nutr 1996: 2: 914.

[2] Liou Cao, Shan Mou, Wei Fang, LeyiGu, Jiaying Huang, AipingGu, JiaqiQian, and Zhaohui Ni. Management of end-stage liver disease. Med. Clin. North Am 2014: 98(1):119-52

[3] (UMMC, 2013; BLT, 2011) University of Maryland Medical Center website. Cirrhosis.Availablet:http://umm.edu/health/m edical/reports/articles/cirrhosis.

[4] Garcia-Tsao, Goldman L, Schafer AI , Chalasani N, Younossi Z, Lavine JE, et al, Goldman's Cecil Medicine, Twenty-Fourth Edition. Chapter 156: CIRRHOSIS AND ITS SEQUELAE 2012: 999-107.

[5] Zhang Y, Proenca R, Maffei M, Barone M, Leopold L and Friedman JM, Positional cloning of the mouse obese gene and itshuman homologue. Nature;1994: 372: 425-432

[6] Tartaglia. LA., CarolaMarzi equal contributor,Eva Albrecht equal contributor,Pirro G. Hysi,VasilikiLagou,MelanieWaldenberger,A nkeT ? njes, et al. The leptin receptor. J BiolChem;1997:272: 6093-6096

[7] Faggioni R, Feingold KR, Grunfeld C., Moser, A., FASEB Leptin regulation ofthe immune response and the immunodeficiency of malnutrition. 2001: J.15: 2565-2571

[8] La Cava A, Alviggi C, Matarese G Matarese G. The weight of leptin in immunity. Nat Rev Immunol; 2004: 4: 371-379

[9] Balci H, Akgun-Dar K, Gazioglu N, Kapucu A, BolayirliM,Oz B. The relationship between prolactin (PRL), leptin, nitric oxide (NO), and cytokines in patients with hyperprolactinemia. Pituitary; 2009: 12: 170176

[10] Lee, A. T. , Lee CG.Oncogenesis and transforming viruses: the hepatitis $\mathrm{B}$ virus and hepatocellularcarcinoma-the etiopathogenic link. Front Biosci; 2007: 234245

[11] Manolakopoulos S, Bethanis S, Liapi C, Stripeli F, Sklavos P, Margeli A, et al. An 
assessment of serum leptin levels in patients with chronic viral hepatitis: a prospective study. BMC Gastroenterol; 2005: 7: 17

[12] Ferrua B, PicheT, Gelsi E, Schneider SM, Hebuterne X, Giudicelli J, Laffont C, Benzaken S, Hastier P, Montoya ML. et al. Fatigue is associated with high circulating leptin levels in chronic hepatitis C. Gut. 2012;51:434-439. doi: 10.1136/gut.51.3.434.

[13] Faggioni R, Feingold KR, Grunfeld C. Leptin regulation of the immune response and the immunodeficiency of malnutrition. 2001: $\mathrm{J}$; 15: 2565-2571

[14] Yang S, Lin HZ, Hwang J, Chacko VP, Diehl AM. Hepatic hyperplasia in noncirrhotic fatty livers: is obesity-related hepaticsteatosis a premalignant condition? Cancer Res 2001: 61:5016-23

[15] Friedman SL, Mechanisms of hepatic fibrogenesis. Gastroenterology 134: 2008: 134:1655-1669

[16] Parkin DM, Brav F, Ferlay J, Pisani P. 2005: Global cancer statistics, CA cancer $\mathrm{J}$ clin,; 55(2):74-108

[17] Magkos F1, Fraterrigo G2, Yoshino J2, Luecking C2, Kirbach K2, Kelly SC2, et al. Effects of Moderate and Subsequent Progressive Weight Loss on Metabolic Function and Adipose Tissue Biology in Humans with Obesity; 2016: 12;23(4):591601

[18] Magkos F, Fabbrini E, Klein S, Pietka T, Abumrad NA, Patterson BW, Okunade A. Pathogenesis of Hepatic Steatosis and V Fibrosis: Role of Leptin. Leptin. 2015 :89101. Leptin Regulation and Clinical Applications. Editors: Sam Dagogo-jack

[19] Magkos F, Fabbrini E, Klein S, Pietka T, Abumrad NA, Patterson BW, Okunade A. Pathogenesis of Hepatic Steatosis and V Fibrosis: Role of Leptin. Leptin. 2015 :89101. Leptin Regulation and Clinical Applications. Editors: Sam Dagogo-jack

[20] Giannini E, Romagnoli F, Tenconi CL, Botta F, Maldatti F, Chiarbonello V, Mamone M, Barreca T, Testa R, High ascitic fluid leptin levels in patients with ecompensated liver cirrhosis and sterile ascitic: relationship with TNF-alpha levels. Dig Sci 2004: 49(2): 27580.

[21] Van Hannelen V, Dicker A, Ryden M, Hauner H, Lonnqvist F, Naslund E, ArnerP Increased lipolysis and decreased leptin production by human omental as compared with subcutaneous preadipocytes. Diabetes
2002: 51 :2029- 2036,

[22] Green R. M., and Flamm, S. AGA technical review on the evaluation of liver chemistry test. Gastroenterology, :2012: 123, 13671384.

[23] Ben-Ari Z, Schaffer Z, Sulkes J, Manhaim V, Tur-Kaspa R, Fainaru M, Alterations in serum leptin in chronic liver disease. Dig Dis Sci, 2002: 47:183-9.

[24] Cortez- pino, Baptista H, Camilo ME and De Moura MC Non-alcoholic steatohepatits - a long-term follow-up study comparison with alcoholic hepatitis. ; 2013: ;48:1909-1913

[25] Riggio O, Angeloni S, Ciuffa L, Nicolini G, Attili AF, Albanese $\mathrm{C}$ and Merli $\mathrm{M}$, Malnutrition is not related to alterations in energy balance in patients with stable liver cirrhosis. Clinical Nutrition; 2003: ; 22 (6): 553-9

[26] Trayhurn P, Thomas MEA, Duh can JS and Rayner DV: Effects of fasting and feeding on ob gene expression in white adipose tissue of lean and obese. (ob/ob) mice. FEBS lett.; 1995: 368: 488-490.

[27] Testa R, Franceschini R, Giannini E, Cataldi A, Botta F, Fasoli A, Tenerelli P, Rolandi E, BarrecaT: Serum leptin levels in patients with viral chronic hepatitis or liver cirrhosis. J Hepatol 2010: 33:33-37,

[28] LeclereqlA, Farrell GC, Schriemer R, et al;: Leptin is essential for the hepatic fibrogenic response to chronic liver injury. Journal of Hepatology; 2012: 37 (2): 206-213.

[29] Wang SN \& Lee KT, Ker CG,: Leptin in hepatocellular carcinoma. World J Gastroenterology.;2010: 16(46):5801-5809

[30] Uygun A, Kadayifci A, Yesilova Z, Erdil A, Yaman H, Saka M, Deveci MS, Bagei S, Gulsen M, Karaeren N, Dagalp K: serum leptin levels in patients with non alcoholic steatohepatitis Am J Gastroenterol 2011: 95: 3524-3588

[31] Saber A, Feria I S, Raafat A, et al.,: Evaluation of serum and ascetic fluid leptin in chronic liver diseases. Tanta Medical sciences 2007: J.;2 (2).

[32] McCullough A J, Bugianesi E, Marchesini G , et al.,: Gender dependent alterations in serum leptin in alcoholic cirrhosis. Gastroenterology 2009: 115:947-953.

[33] Tungtrongchitr R, Treeprasertsuk S, Ei NN, et al.,: Serum leptin concentrations in chronic hepatitis .I Med Assoc hai 2006: 89( 4):4909. 